\title{
Effect of a Small Concentration of Iron Impurity on the Oxidation Behavior of Porous SiC
}

\author{
Hayato NANRI, Mitsuru SHIRAI, Nobuyuki TAKEUCHI, Shingo ISHIDA, \\ Koji WATANABE* and Mitsuru WAKAMATSU* \\ Department of Chemistry and Materials Technology, Kyoto Institute of Technology, Matsugasaki, Sakyo-ku, Kyoto-shi 606 \\ *Taiko Refractories Co., Ltd., 1-1, Makiyama Shinmachi, Tobata-ku, Kitakyushu-shi 804
}

\author{
多孔質 SiC の酸化に及ぼす鉄不純物の影響 \\ 南里隼人 $\cdot$ 白井 充·竹内信行 $\cdot$ 石田信伍 $\cdot$ 渡部公士*·若松 盈* \\ 京都工芸瀻維大学工芸学部物質工学科, 606 京都市左京区松ヶ崎御所海道町 \\ *大光炉材 (株)，804 北九州市戸畑区牧山新町 1-1
}

\begin{abstract}
Oxidation behavior of porous $\mathrm{SiC}$ containing $\mathrm{Fe}$ was investigated using a quadrupole mass spectrometer by measuring the volume of evolved gases during oxidation at $1700 \mathrm{~K}$. This Fe-containing $\mathrm{SiC}$ was obtained by immersing the $\mathrm{SiC}$ in an acetone solution with an $\mathrm{Fe}\left(\mathrm{C}_{5} \mathrm{H}_{7} \mathrm{O}_{2}\right)_{3}$ concentration of $0.1 \mathrm{M}$ for 1-5 min followed by calcination at $1173 \mathrm{~K}$. The weight gain and the total amount of gases evolved decreased with increasing $\mathrm{Fe}_{2} \mathrm{O}_{3}$ content. XRD intensity ratio of cristobalite to $\mathrm{SiC}$ was increased with increasing $\mathrm{Fe}_{2} \mathrm{O}_{3}$ content. These results indicate that the accelerated crystallization of amorphous silica to cristobalite and the retardation of the oxidation were caused by the added Fe.

[Received December 11, 1996; Accepted March 11, 1997]
\end{abstract}

Key-words : Mass spectrometer, Porous SiC, Impurity, Fe

\section{Introduction}

It is well known that sintering aids and impurities contained in $\mathrm{SiC}$ and $\mathrm{Si}_{3} \mathrm{~N}_{4}$ ceramics significantly affected their oxidation-resistive properties. ${ }^{1)-5)}$ A number of reports have been published on the effects of $\mathrm{Al}, \mathrm{Na}$ and $\mathrm{K}$ impurities in these typical non-oxide ceramics, ${ }^{6)-8)}$ but the effect of $\mathrm{Fe}$ has scarcely been investigated although it is an omnipresent impurity in them. ${ }^{9)}$ Ishikawa et al. studied oxidation behaviors of powdery $\mathrm{Si}_{3} \mathrm{~N}_{4}$ materials with different $\mathrm{Fe}$ content and tried to clarify the effect of the iron impurity on the oxidation resistances of the materials. ${ }^{1)}$ Their attempt was not successful probably due to larger contributions of coexisting $\mathrm{Al}_{2} \mathrm{O}_{3}$ and $\mathrm{Y}_{2} \mathrm{O}_{3}$ added as sintering aids to the oxidation resistances. Suzuki ${ }^{9)}$ carried out oxidation experiments for powdery $\mathrm{SiC}$ materials added with as much as 5 mass $\% \mathrm{Fe}_{2} \mathrm{O}_{3}$ (hereafter mass $\%$ is abbreviated merely as $\%)$. It is likely that, at this $\mathrm{Fe}_{2} \mathrm{O}_{3}$ content, most of $\mathrm{Fe}_{2} \mathrm{O}_{3}$ forms a secondary phase and obscures the effect of $\mathrm{Fe}$ bonded with the passive $\mathrm{SiO}_{2}$ layer covering $\mathrm{SiC}$ particles. Thus, his results are not of value for reference concerning the effect of the Fe impurity. In addition, it seems worth mentioning that commercially available $\mathrm{SiC}$ materials usually contain less than $0.1 \% \mathrm{Fe}^{10}$ )

In the present study, high-purity $\mathrm{SiC}$ ceramics was selected as a testing material to exclude or reduce the influence of impurities other than intentionally added Fe. This SiC ceramics was porous probably because it was sintered without any sintering aid. The oxidation behaviors of the porous $\mathrm{SiC}$ ceramics added with different concentrations of Fe were investigated using a quadrupole mass spectrometer by quantitatively measuring evolved gases during oxidation. This paper, mainly dealing with interrelations of the Fe content, the oxidation behavior and the microstructure of the surface $\mathrm{SiO}_{2}$ layer, intends to clarify the effect of $\mathrm{Fe}$ on the oxidation-resistive property of $\mathrm{SiC}$ ceramics from the microscopic viewpoint.

It should be noted that promotion of the durability of nonoxide ceramics at high temperatures is of great industrial importance. Another intention of this study is to establish the method to enhance the oxidation resistance of $\mathrm{SiC}$ ceramics.

\section{Experimental procedure}

High-purity porous $\mathrm{SiC}$ ceramic plate purchased from Ibiden Co., Ltd. ${ }^{11)}$ was cut into rectangular bars of $3 \times 4 \times$ $40 \mathrm{~mm}$. These bars were heated at $1200 \mathrm{~K}$ in air for $1 \mathrm{~h}$ to remove the free carbon. Iron acetylacetonate $\left(\mathrm{Fe}\left(\mathrm{C}_{5} \mathrm{H}_{7} \mathrm{O}_{2}\right)_{3}\right.$, FeAcac) from Nacalai Tesque Inc. was used as the source of $\mathrm{Fe}$. The $\mathrm{SiC}$ bar was immersed in an acetone solution with the FeAcac concentration of $0.1 \mathrm{M}$ for $60-300 \mathrm{~s}$ followed by being dried and successively calcined at $1173 \mathrm{~K}$ for $1 \mathrm{~h}$. This Fe-doping process converts FeAcac into iron oxide.

Electron probe microanalyzer (EPMA) measurements of the cross section of the resulting samples could not detect the local enrichment of $\mathrm{Fe}$, indicating that $\mathrm{Fe}$ was homogeneously distributed in pores of the sample. X-ray diffraction (XRD) analysis of the samples revealed that the impregnated $\mathrm{Fe}$ was changed to $\mathrm{Fe}_{2} \mathrm{O}_{3}$. The $\mathrm{Fe}_{2} \mathrm{O}_{3}$ content in the Fe-doped sample was calculated from the following Eq. (1),

$$
\mathrm{Fe}_{2} \mathrm{O}_{3} \text { content }(\%)=100\left(W_{1}-W_{0}\right) / W_{0}
$$

where $W_{0}$ and $W_{1}$ are the weight of the SiC bar before the immersing treatment and that after the Fe-doping process, respectively. The Fe-doped sample was heated to $1700 \mathrm{~K}$ with a temperature-rising rate of $5 \mathrm{~K} / \mathrm{min}$ and then soaked for $15 \mathrm{~h}$. The oxidation test of the Fe-doped sample was almost the same as mentioned in the previous paper, ${ }^{11)}$ in the present experiments, oxygen partial pressure $\left(P_{\mathrm{O}_{2}}\right)$ being fixed at $2 \mathrm{kPa}$. It seems necessary to note that the oxidation kinetics for high-purity porous $\mathrm{SiC}$ at $P_{\mathrm{O}_{2}}$ of $2 \mathrm{kPa}$ obeyed the parabolic law and its oxidation type was classified into the mild oxidation. ${ }^{11)}$ In the present study, oxidation behaviors of the Fe-doped samples were analyzed also from the kinetic standpoint.

Weights of the Fe-doped sample before and after the oxidation test were measured, the difference between them being a measure of the oxidized fraction of the sample. 
$\mathrm{XRD}$ analysis and scanning electron microscope (SEM) analysis for the sample after the oxidation test were performed to investigate the effect of $\mathrm{Fe}$.

\section{Results and discussion}

3.1 Amount of gas evolved and weight change During oxidation, $\mathrm{CO}_{2}$ and $\mathrm{CO}$ were evolved according to Eqs. (2) and (3). Evolution rates of $\mathrm{CO}_{2}$ and $\mathrm{CO}$ are shown in Fig. 1 and Fig. 2, respectively. The point of time 0 in Fig. 1 means that at that time, the temperature around the sample reached the soaking temperature $(1700 \mathrm{~K})$. In the cases of $\mathrm{Fe}_{2} \mathrm{O}_{3}=0$ and $0.13 \%$, the evolution rate reached a maximum immediately after the onset of the soaking at $1700 \mathrm{~K}$ and decreased with the soaking time. In the cases of $\mathrm{Fe}_{2} \mathrm{O}_{3}=0.24$ and $0.37 \%$, the evolution rate reached a maximum before the onset of the soaking at $1700 \mathrm{~K}$ and decreased abruptly. These facts indicate that the passive oxidation as represented by the following equations, occurred at this oxygen partial pressure.

$$
\begin{aligned}
& \mathrm{SiC}+2 \mathrm{O}_{2}=\mathrm{SiO}_{2}+\mathrm{CO}_{2} \\
& \mathrm{SiC}+3 / 2 \mathrm{O}_{2}=\mathrm{SiO}_{2}+\mathrm{CO}
\end{aligned}
$$

Integration curves plotting total amount of $\mathrm{CO}_{2}$ and $\mathrm{CO}$ gases evolved (hereafter abbreviated as gas amount) as a function of the oxidation time were shown in Fig. 3. This figure shows that the gas amount decreased with increasing $\mathrm{Fe}_{2} \mathrm{O}_{3}$. In the case of $0.13 \% \mathrm{Fe}_{2} \mathrm{O}_{3}$ sample, the gas amount

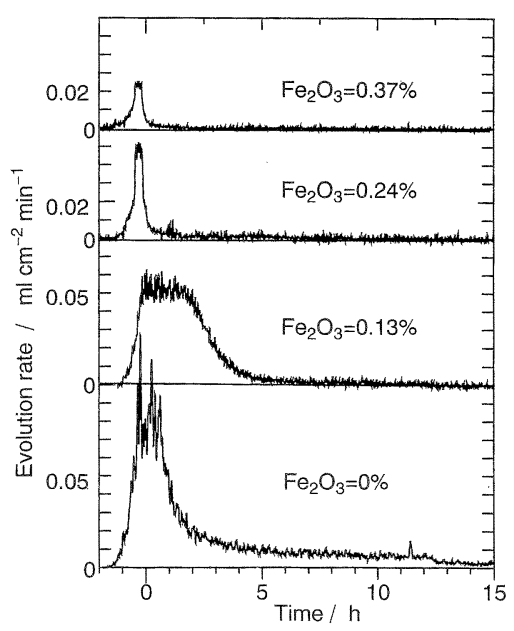

Fig. 1. $\mathrm{CO}_{2}$ evolution rate during oxidation of porous $\mathrm{SiC}$ containing various amounts of $\mathrm{Fe}_{2} \mathrm{O}_{3}$ at $1700 \mathrm{~K}$.

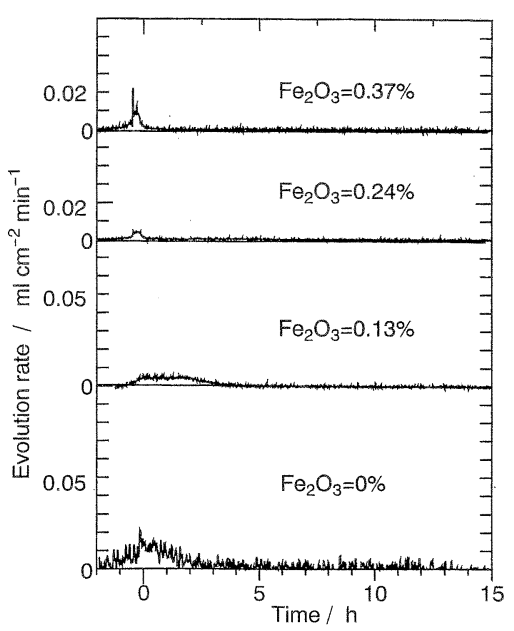

Fig. 2. CO evolution rate during oxidation of porous $\mathrm{SiC}$ containing various amounts of $\mathrm{Fe}_{2} \mathrm{O}_{3}$ at $1700 \mathrm{~K}$. was almost the same as that in the case of Fe-undoped sample, while, in the case of $0.24 \% \mathrm{Fe}_{2} \mathrm{O}_{3}$ sample, the gas amount decreased to $1 / 6$ of that in the case of Fe-undoped sample. These facts indicate that a critical $\mathrm{Fe}_{2} \mathrm{O}_{3}$ content lies between 0.13 and $0.24 \%$ at which $\mathrm{Fe}$ exerts a remarkable effect in enhancing the oxidation resistance.

In the case of $0.13 \% \mathrm{Fe}_{2} \mathrm{O}_{3}$ sample, the gas evolution continued for the oxidation time of $10 \mathrm{~h}$. In the cases of $0.24 \%$ and $0.37 \% \quad \mathrm{Fe}_{2} \mathrm{O}_{3}$ samples, the gas evolutions almost stopped at the oxidation times of $6 \mathrm{~h}$ and $1 \mathrm{~h}$, respectively. The period where the gas evolution could be observed decreased with increasing the $\mathrm{Fe}_{2} \mathrm{O}_{3}$ content.

In order to examine whether the oxidation behaviors of the Fe-doped samples can be classified into the parabolic type or not, the parabolic plots for the total amount of $\mathrm{CO}_{2}$ and $\mathrm{CO}$ evolved were made and shown in Fig. 4. The plotted line must draw the straight line when the oxidation kinetics obeys the parabolic law. In the case of the Fe-undoped sample, the integration curve obeyed the parabolic law in the oxidation time range from 2 to $12 \mathrm{~h}$.

In the cases of the Fe-doped samples, the plots drew the straight lines only around the time 0 , that is near the onset of the oxidation, changing later to the flat line. These results indicated that the oxidation behaviors of the Fedoped samples could not be classified into the parabolic type. Porz and Thummler ${ }^{12)}$ found the deviation of the plotted curve from the parabolic law when porous silicon nitride ceramics was oxidized. They explained this phenomenon as follows. When the pore is filled with oxidation products the oxidation in the pore stops abruptly and the overall reaction

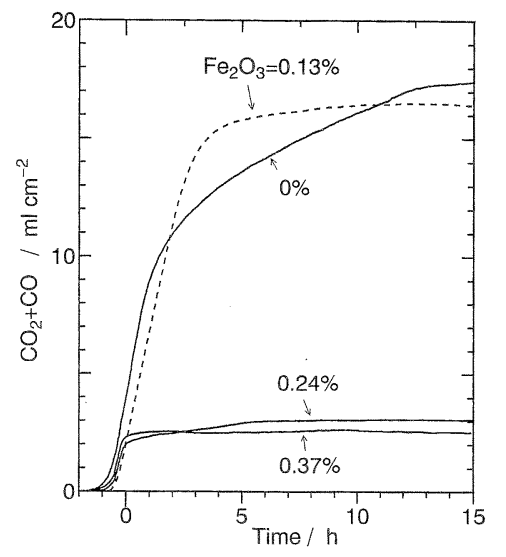

Fig. 3. Amount of gases $\left(\mathrm{CO}_{2}+\mathrm{CO}\right)$ evolved during oxidation of porous $\mathrm{SiC}$ containing various amounts of $\mathrm{Fe}_{2} \mathrm{O}_{3}$ at $1700 \mathrm{~K}$.

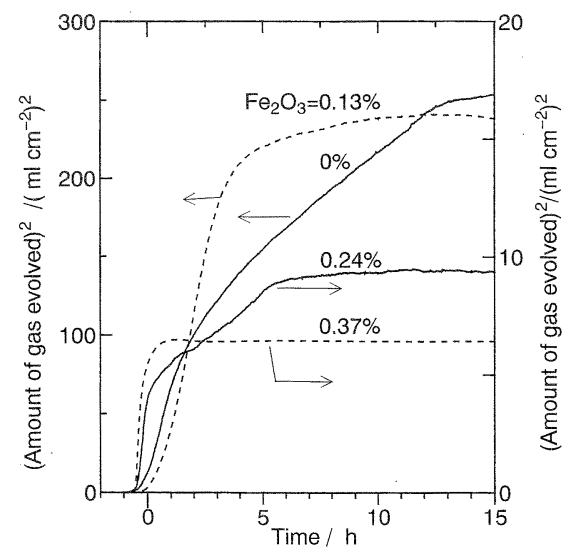

Fig. 4. Parabolic plots of gas evolved during oxidation of porous $\mathrm{SiC}$ containing various amounts of $\mathrm{Fe}_{2} \mathrm{O}_{3}$ at $1700 \mathrm{~K}$. 
proceeds according to the asymptotic law rather than the parabolic law. Similarly to the above case, oxidation behaviors deviating from the parabolic kinetics have often been found. Narushima et al. ${ }^{13)}$ analyzed the oxidation behavior of $\mathrm{SiC}$ by the use of the parabolic plot and observed the gradient change in the plotted line. They attributed it to the crystallization of amorphous silica to cristobalite which caused the enhanced oxidation resistance. Examination of the oxidation kinetics for the Fe-doped samples showed that $0.13 \% \mathrm{Fe}_{2} \mathrm{O}_{3}$ case roughly fitted with the asymptotic law but its adaptability to 0.24 and $0.37 \%$ cases could not be judged because of the too rapid completion of the oxidation. Similarity observed in Fig. 3 among the curves for $0.13,0.24$ and $0.37 \% \mathrm{Fe}_{2} \mathrm{O}_{3}$ samples, however, suggests that the asymptotic law is more suitable as the oxidation kinetics for the Fe-doped samples.

Cristobalite was detected as an oxidation product by XRD measurement of the surface layer of the sample after the oxidation. Figure 5 shows the X-ray intensity ratio of (101) peak of cristobalite to (111) peak of SiC along with the weight change of the sample before and after the oxidation and the total amount of gases evolved during the oxidation. The X-ray intensity ratio of cristobalite to $\mathrm{SiC}$ was increased with increasing the $\mathrm{Fe}_{2} \mathrm{O}_{3}$ content from 0.13 to $0.24 \%$ and then was decreased. $\mathrm{SiC}$ and cristobalite were detected on the surface of the samples after the oxidation in the cases of $\mathrm{Fe}_{2} \mathrm{O}_{3}=0.13$ and $0.24 \%$. SiC, cristobalite and $\mathrm{Fe}_{2} \mathrm{O}_{3}$ were detected in the cases of $\mathrm{Fe}_{2} \mathrm{O}_{3}=0.37$ and $0.43 \%$. The weight gain was decreased with increasing the $\mathrm{Fe}_{2} \mathrm{O}_{3}$ content until $\mathrm{Fe}_{2} \mathrm{O}_{3}=0.37 \%$ and then increased at around $\mathrm{Fe}_{2} \mathrm{O}_{3}=0.43 \%$. The total amount of gases evolved showed the similar tendency as the weight gain. At $\mathrm{Fe}_{2} \mathrm{O}_{3}=0.24$ and $0.37 \%$, the weight gain showed the lowest value, indicating that the appropriate content of $\mathrm{Fe}_{2} \mathrm{O}_{3}$ to promote the oxidation resistance of the $\mathrm{SiC}$ sample lies between 0.24 and $0.37 \%$. These results suggest that the degree of crystallinity of cristobalite acting as the protective film was increased although the thickness of the cristobalite film was decreased with increasing the $\mathrm{Fe}_{2} \mathrm{O}_{3}$ content. In order to ascertain the above assumption, the half width was measured for (101) peak of cristobalite in the Fe-doped samples after the oxidation.

Figure 6 shows the relation between the half width of (101) peak of cristobalite and the $\mathrm{Fe}_{2} \mathrm{O}_{3}$ content. The half width was decreased with increasing the $\mathrm{Fe}_{2} \mathrm{O}_{3}$ content from 0.13 to $0.24 \%$ and then was increased. These results demonstrate that there is the most appropriate $\mathrm{Fe}_{2} \mathrm{O}_{3}$ content around $0.24 \%$ for the crystallization of cristobalite.

\subsection{Porosity and microstructure}

Figure 7 shows the relation between apparent porosity and the $\mathrm{Fe}_{2} \mathrm{O}_{3}$ content of the Fe-doped sample. The apparent porosity was measured by Archimedean method using water, the measured samples being oxidized ones which were not pulverized. At $0.13 \% \mathrm{Fe}_{2} \mathrm{O}_{3}$, the apparent porosity showed the lowest value and then was increased with the increasing $\mathrm{Fe}_{2} \mathrm{O}_{3}$ until $0.37 \%$. By considering that the oxidation product accumulate in the pore, conformity of the tendency for the apparent porosity with that for the weight gain except the undoped case can be well explained. Preservation of comparatively higher porosity irrespective of the large weight gain observed for the undoped sample after oxidation suggests that the pore-filling mechanism was different between the Fe-doped and Fe-undoped samples. The previous paper ${ }^{11)}$ dealing with high-purity porous $\mathrm{SiC}$ showed that $\mathrm{SiO}_{2}$ deposited on the external surface and in pores equally. The present results show that the $\mathrm{SiO}_{2}$ deposition in pores was enhanced by the Fe-doping.

If, as suggested by Porz and Thummler, ${ }^{12)}$ the asymptotic oxidation behavior of porous $\mathrm{SiC}$ was caused by closure of openings of pores, the apparent porosity would become a minimum at the $\mathrm{Fe}_{2} \mathrm{O}_{3}$ content around $0.24 \%$, but this is not the case. It seems reasonable to alternatively consider that the asymptote-like oxidation kinetics of the Fe-doped sample was governed by the degree of crystallization of the protective $\mathrm{SiO}_{2}$ layer formed during the oxidation.

Figure 8 shows the SEM photographs of the surface of the samples after the oxidation. The sample with $0.13 \%$ $\mathrm{Fe}_{2} \mathrm{O}_{3}$ had almost the same surface microstructure as the Fe-undoped sample. In the case of $0.24 \% \mathrm{Fe}_{2} \mathrm{O}_{3}$ sample, its surface was covered by the oxidation product in which comparatively small pores were seen and most of pores which were present before the oxidation, disappeared. Flatly deposited oxidation product suggests that it was crystallized from low viscosity melt. Cracks which arose probably accompanying the transformation of cristobalite from $\beta$ to $\alpha$ were observed in the oxidation product on the surface. In the case of $0.37 \% \mathrm{Fe}_{2} \mathrm{O}_{3}$ sample, the dendritic product was formed mounting on the glassy product.

The amount of Fe needed to cover the total surface area of the pores was calculated as follows. FeAcac absorbed

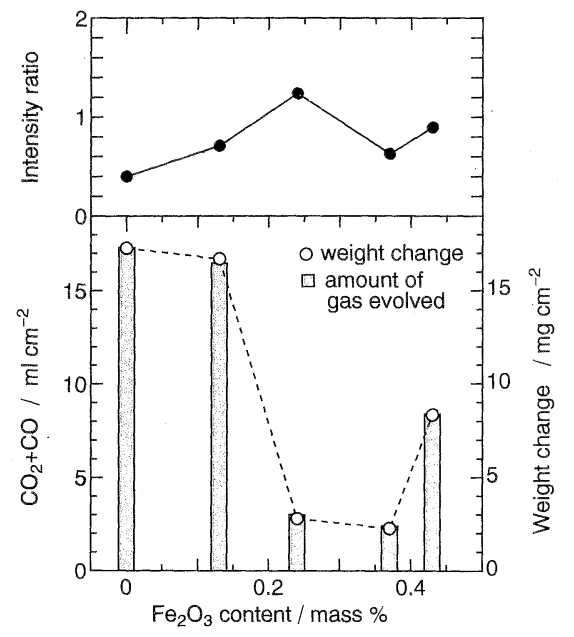

Fig. 5

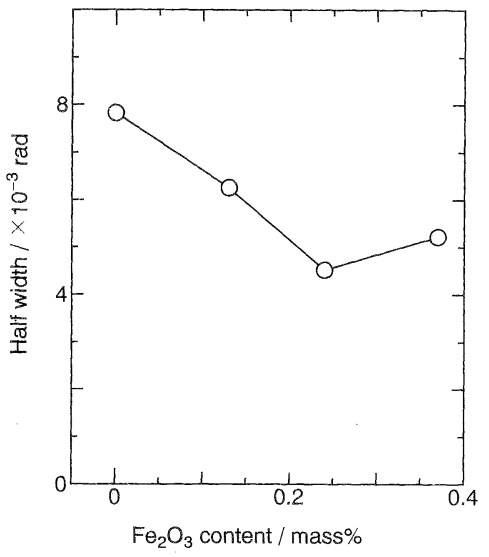

Fig. 6

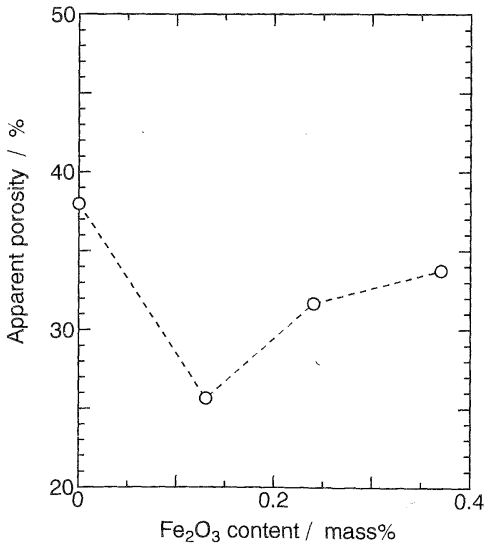

Fig. 7

Fig. 5. XRD intensity ratio of cristobalite (101)/ $\mathrm{SiC}(111)$, amount of gas evolved and weight change after oxidation.

Fig. 6. Half width of cristobalite (101) as a function of $\mathrm{Fe}_{2} \mathrm{O}_{3}$ content.

Fig. 7. Relation between apparent porosity and $\mathrm{Fe}_{2} \mathrm{O}_{3}$ content of porous $\mathrm{SiC}$ after oxidation at $1700 \mathrm{~K}$. 


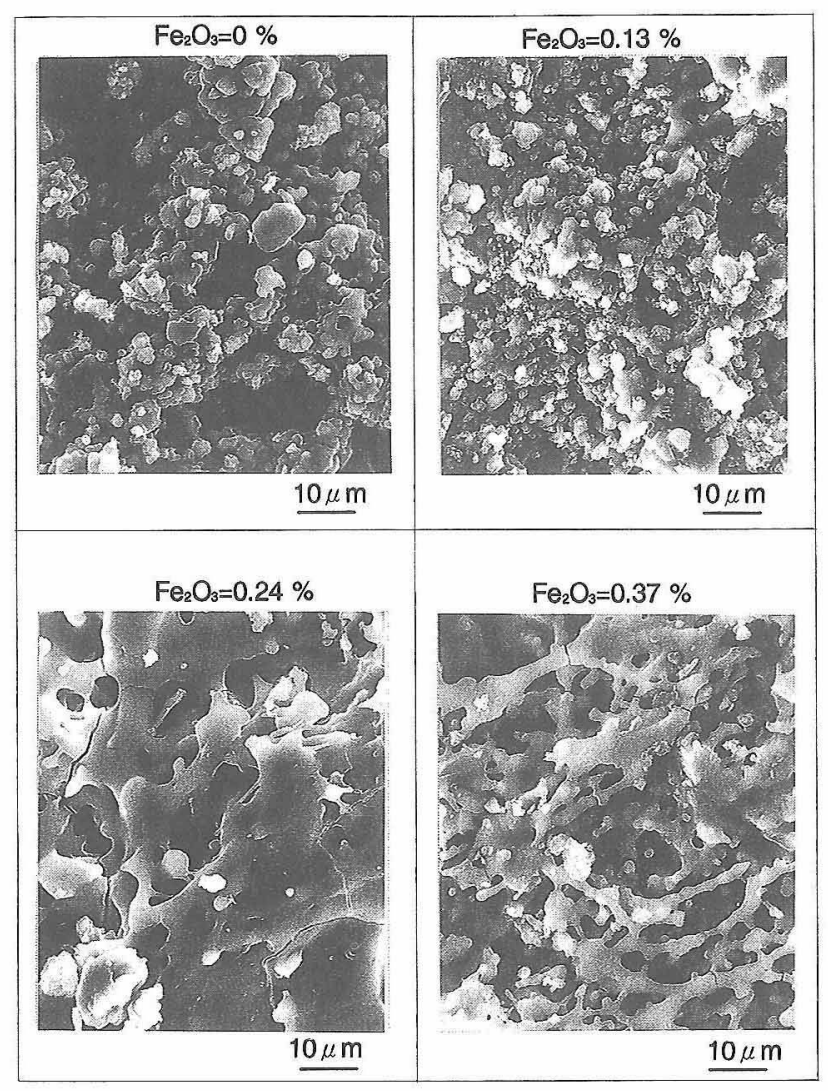

Fig. 8. Scanning electron micrographs of the surface of the porous $\mathrm{SiC}$ containing $\mathrm{Fe}_{2} \mathrm{O}_{3}$ after oxidation at $1700 \mathrm{~K}$ for $15 \mathrm{~h}$ in $\mathrm{Ar}-\mathrm{O}_{2}\left(P_{\mathrm{O}_{2}}=2 \mathrm{kPa}\right)$.

into the pores decomposes to $\mathrm{FeO}$ in the intermediate stage of the calcination process. $\mathrm{FeO}$ would be well dispersed on the internal surface of the pores due to the significant acidbase interaction between $\mathrm{SiO}_{2}$ (acid) and $\mathrm{FeO}$ (base). The average pore diameter of the starting porous $\mathrm{SiC}$ materials is $1.5 \mu \mathrm{m} .{ }^{11)}$ The total surface area of the pores in the starting sample $(3 \times 4 \times 40 \mathrm{~mm})$ was calculated to be $0.61 \mathrm{~m}^{2}$ from the porosity (48.4\%) and the bulk density $(1.56 \mathrm{~g} /$ $\mathrm{cm}^{3}$ ) data, and by assuming the pores cylindrically shaped with their diameters all $1.5 \mu \mathrm{m}$. When the monolayer composed of unit cells of wuestite $\left(a=0.43 \mathrm{~nm},{ }^{17}\right) 4 \mathrm{FeO}$ contained) covers the area of $0.61 \mathrm{~m}^{2}$, its amount is calculated to be $1.6 \mathrm{mg}$, which corresponds to $1.7 \mathrm{mg} \mathrm{Fe} 2 \mathrm{O}_{3}$ or $0.23 \%$ $\mathrm{Fe}_{2} \mathrm{O}_{3}$ in the $\mathrm{Fe}$-doped sample. This value of $0.23 \%$ is very close to the $\mathrm{Fe}_{2} \mathrm{O}_{3}$ content of the sample which showed the highest crystallinity of cristobalite after the oxidation. FeO intermediately formed in the pores must convert to $\mathrm{Fe}_{2} \mathrm{O}_{3}$ in the final stage of the calcination process but would be regenerated in the early stage of the oxidation where both $\mathrm{CO}$ and $\mathrm{CO}_{2}$ can be detected in the ambient atmosphere.

3.3 Reaction between $\mathrm{FeO}$ and $\mathrm{SiO}_{2}$ layer

As a due course, reaction of $\mathrm{SiO}_{2}$ as the oxidation product with $\mathrm{FeO}$ must be discussed along with its effect on the oxidation behaviors of Fe-doped samples. The present authors recently clarified that cooperative action of $\mathrm{Fe}^{2+}$ and $\mathrm{Fe}^{3+}$ markedly promoted the crystallization of amorphous $\mathrm{SiO}_{2}$ to cristobalite. ${ }^{14)}$

The conversion to cristobalite would be suppressed if the doped amount of $\mathrm{Fe}_{2} \mathrm{O}_{3}$ was not sufficient to cover the entire surface of the pores. This situation corresponds to the sam- ple with $0.13 \% \mathrm{Fe}_{2} \mathrm{O}_{3}$ content, passivation of which needed as long as $10 \mathrm{~h}$.

Formation of a liquid phase was suggested during the oxidation by the SEM observation of the oxidized samples. In the case of $0.37 \% \mathrm{Fe}_{2} \mathrm{O}_{3}$ sample, the amount of $\mathrm{SiO}_{2}$ formed until its passivation was calculated to be about $13 \mathrm{mg}$, which is much larger than the $\mathrm{Fe}_{2} \mathrm{O}_{3}$ content. The phase diagram for $\mathrm{SiO}_{2}-\mathrm{FeO}^{15)}$ shows that in the $\mathrm{SiO}_{2}$-rich region, a liquid phase and tridymite coexist at $1700 \mathrm{~K}$ at the equilibrium state, but since it costs long time to attain the equilibrium, cristobalite has often been found to be the major species in this region. ${ }^{16}$ )

Since in the present study, the pore volumes of the samples were reduced after the oxidation, contribution of the pore-mouth blocking to their oxidation behaviors can not be excluded, but the incomplete blocking observed for the passivated sample strongly indicate that the other mechanism must be operative. A crystallization-induced passivation model proposed by the present authors seems to be more valid than the pore-mouth blocking model. More detailed mechanistic investigation is now in progress and will be published elsewhere.

\section{Conclusion}

Oxidation behaviors of porous $\mathrm{SiC}$ ceramics intentionally doped with $0.13-0.43 \% \mathrm{Fe}_{2} \mathrm{O}_{3}$ in $\mathrm{Ar}-\mathrm{O}_{2}$ atmosphere $\left(P_{\mathrm{O}_{2}}\right.$ $=2 \mathrm{kPa})$ at $1700 \mathrm{~K}$ for $15 \mathrm{~h}$ were investigated and following results were obtained.

(1) Doped $\mathrm{Fe}_{2} \mathrm{O}_{3}$ enhanced the oxidation resistance of the $\mathrm{SiC}$ ceramics. At the $\mathrm{Fe}_{2} \mathrm{O}_{3}$ contents of 0.24 and $0.37 \%$, Fe-doped samples exhibited about $1 / 6$ of the weight gain of Fe-undoped sample.

(2) Doped $\mathrm{Fe}_{2} \mathrm{O}_{3}$ promoted the yield and the crystallinity of cristobalite formed during the oxidation. Cristobalite was considered to act as a protective film against the oxidation and a crystallization-induced passivation model was proposed.

\section{References}

1) M. Ishikawa, N. Takeuchi, S. Ishida, $M$. Wakamatsu and $K$. Watanabe, J. Soc. Mater. Sci. Japan, 42, 512-16 (1993).

2) S. C. Singhal, J. Mater. Sci., 11, 500-09 (1976).

3) S. C. Singhal, J. Mater. Sci., 11, 1246-53 (1976).

4) J. A. Costello and R. E. Tressler, J. Am. Ceram. Soc., 64 , 327-31. (1981).

5) J. A. Costello and R. E. Tressler, J. Am. Ceram. Soc., 69, 674-81 (1986).

6) E. Opila, J. Am. Ceram. Soc., 78, 1107-10 (1995).

7) S. C. Singhal and F. F. Lange, J. Am. Ceram. Soc., 58, 433-35 (1975).

8) V. Pareek and D. A. Shores, J. Am. Ceram. Soc., 74, 556-63 (1991).

9) H. Suzuki, Yogyo-Kyokai-Shi, 67, 189-95 (1959).

10) "Fine Ceramic Data Book," Nikkan Kogyo Shinbunsha (1994) pp. 30-83.

11) H. Nanri, M. Shirai, N. Takeuchi, S. Ishida, K. Watanabe and M. Wakamatsu, J. Ceram. Soc. Japan, 104, 738-42 (1996).

12) F. Porz and F. Thummler, J. Mater. Sci., 19, 1283-95 (1984).

13) T. Narushima, T. Goto and H. Hirai, J. Am. Ceram. Soc., 72, 1386-90 (1989).

14) H. Nanri, N. Takeuchi, S. Ishida, K. Watanabe and M. Wakamatsu, J. Non-Cryst. Solids, 203, 375-79 (1996).

15) N. L. Bowen and J. L. Schairer, Am. J. Sci., 24, 177-213 (1932).

16) A. Nukui, Seramikkusu, 20, 266-73 (1985).

17) “Rikagakujiten”, 3rd ed., Iwanami Shoten (1983) p. 515. 